\title{
Processing of Brazil-nut flour: characterization, thermal and morphological analysis
}

\author{
Processamento de farinha de castanha-do-brasil: caracterização, análises térmicas e morfológicas
}

\author{
Orquídea Vasconcelos dos SANTOS ${ }^{1,2,3 *}$, Alessandra Santos LOPES 2 , \\ Glaucinéia Oliveira AZEVEDO ${ }^{2}$, Ângela Chagas SANTOS ${ }^{2}$
}

\begin{abstract}
The Brazil nut (Bertholletia excelsea H. B. K.) is noteworthy for its high content of lipids and proteins of elevated biological value and these factors justify the need for further research and incentives for the manufacturing of new trade products. In the present study we sought new forms of technological use of these nuts by the food industry, through their processing as flour, with no alteration in its energy content. The results after its elaboration showed a product with high energy value (431.48 kcal.100 g-1), protein content of $45.92 \mathrm{~g} .100 \mathrm{~g}^{-1}$, and fiber of $17.14 \%$. The thermal analyses indicate that the introduction of another protein component, such as soy protein isolate, does not alter the reactions or thermal behavior. On the other hand, morphological analyses revealed granular structures similar to the structure of globular proteins. It was observed that after processing to obtain the flour, the product maintains its protein-energy content, as well as its characteristics when subjected to high temperatures.
\end{abstract}

Keywords: Brazil nut; thermal analysis; morphological analysis.

\section{Resumo}

A castanha-do-Brasil (Bertholletia excelsea H. B. K.) destaca-se por seus elevados teores em lipídios e proteínas de alta qualidade biológica, parâmetros que justificam a necessidade de maiores pesquisas e incentivos para a elaboração de novos produtos comerciais. No presente estudo, busca-se identificar novas formas de aproveitamento tecnológico dessas amêndoas pela indústria alimentícia, através de seu processamento sobre a forma de farinha sem alteração do teor energético. Os resultados após sua elaboração mostraram um produto com alto valor energético $431,48 \mathrm{kcal} .100 \mathrm{~g}^{-1}$, teor de proteína de 45,92 g.100 g $\mathrm{g}^{-1}$ e fibra alimentar de 17,14\%. As análises térmicas indicam que a introdução de outro componente proteico, como o isolado proteico de soja, não altera as reações e comportamentos térmicos. Já as morfológicas evidenciaram estruturas granulares semelhantes à estrutura das matrizes de proteínas globulares. Constata-se que, após o processamento e obtenção de farinha, o produto mantém seu alto teor energético-proteico e, ao ser submetido a altas temperaturas, mantém suas características.

Palavras-chave: castanha-do-Brasil; análise térmica; análise morfológica.

\section{Introduction}

The Brazil nut is defined as the seed of the Brazil nut tree (Bertholletia excelsea H. B. K.), a plant of the Lecythidaceae family. It is found in a vast region in Latin America, mainly in the Amazon region (SOUZA, 1999; GLÓRIA; REGITANO-d 'ARCE, 2000).

From the nutritional point of view, the oleaginous fruits are excellent sources of essential nutrients for organic balance. The nutritional composition of Brazil nuts shows a high content of lipids (60-70\%) and proteins (15-20\%) and features, as a differential point, the elevated content of methionine, an essential amino acid which is deficient in many proteins produced by vegetables, mainly leguminous plants (COUTINHO; COZZOLINO, 1998; CARDARELLI; OLIVEIRA, 2000; GONZAGA, 2002).

As a consequence of its high percentage of selenium and unsaturated lipids, some fruits, such as Brazil nuts, present properties which lead them to be named functional foods (SGARBIERI, 1996; IÑARRITU; FRANCO, 2001).
The Brazil nut is also used by natives of the Amazon region, for culinary purposes and in the preparation of typical foods. Brazil nut milk, for example, is consumed pure, mainly in infant nutrition and also in regional dishes. The flour is used in the preparation of biscuits, candies, cakes and for enriching other flours (CAMARGO; CASTRO; GAVILANES, 2000; FERBERG et al., 2006).

The nut can be consumed in many forms, in natura, dehydrated, salted, toasted, covered with chocolate, caramel, sugar, honey and other toppings. It also can be used in products such as granola, ice-creams, chocolates, cakes, breakfast cereals, snacks, candies and biscuits, such as flour or "milk" (CAMARGO; CASTRO; GAVILANES, 2000; VILHENA, 2004; BOWLES; DEMIATE, 2006; FERBERG et al., 2006).

In this context, the possibility that the industry might produce defatted Brazil-nut flour as a raw material or as a component of enriched mixtures should be considered.

${ }^{1}$ Escola Superior da Amazônia - ESAMAZ (Educação Física/Enfermagem/Nutrição), Belém - PA, Brasil, E-mail: orquideavs@usp.com.br

${ }^{2}$ Faculdade de Engenharia de Alimentos, Universidade Federal do Pará, CEP 66075-110, Belém - PA, Brasil

${ }^{3}$ Departamento de Tecnologia Bioquímico-Farmacêutica, Universidade de São Paulo - USP, CEP 05508-900, São Paulo - SP, Brasil

${ }^{*}$ A quem a correspondência deve ser enviada 
The aim of this work is to evaluate whether the product maintains its high energy-protein content after processing, as well as its characteristics after being subjected to high temperatures. To achieve this, the following analyses will be carried out: physico-chemical, thermal and morphological characterization of the flour.

\section{Materials and methods}

\subsection{Raw materials}

Around $40 \mathrm{~kg}$ of Brazil nuts, obtained from the company Benedito Mutran Cia Ltda (April 2007 harvest) were used. The nuts were broken, peeled, transported in flexible laminated packaging and cardboard boxes, stored in polystyrene boxes at $-18^{\circ} \mathrm{C}$ at the Laboratory of Operations and Separation (LAOS) of the Federal University of Pará (UFPA).

\subsection{Processing of the nuts for obtaining the flour}

The samples of Brazil nuts were previously dried at $50{ }^{\circ} \mathrm{C}$ for 24 hours. This step was carried out in a FABBE model 170 oven.

Fat extraction was carried out using a MARCON MPH15 hydraulic press with a capacity of 15 tons of pressure at the Laboratory of Operations and Separation (LAOS) of UFPA. The paste obtained following the fat extraction presented reduced lipid contents.

The process for obtaining the defatted flour is presented as a flowchart in Figure 1.

The defatted paste was ground in a Willye-type mill (TECNAL model TE650), followed by the elaboration of defatted Brazil-nut flour.

The resulting product was vacuum-packaged in polyethylene bags and stored in polystyrene boxes, in the dark, at $-18^{\circ} \mathrm{C}$, in the Food Works Laboratory of UFPA.

\subsection{Analyses carried out with the defatted Brazil-nut flour}

\section{Physico-chemical analyses}

For physico-chemical determinations, analyses of water activity, ash, moisture, lipids and proteins (Kjeldahl method with a factor of $5.46 \times \% \mathrm{~N}$ ) were performed according to the methodology of the Association of Official Analytical Chemists - AOAC (1997). Carbohydrates were estimated by difference (100 minus the sum of humidity, lipid, protein, ash and fiber values), the total energy content as kcal was obtained by using the Atwater index of $4 \mathrm{kcal}$ for carbohydrates and proteins and $9 \mathrm{kcal} .100 \mathrm{~g}^{-1}$ for lipids.

\section{Thermal analyses of the defatted Brazil-nut flour}

For the characterization of the main changes and thermal transformations which might occur during temperature increases of the flour and its behavior when mixed with other products, a proportion of $20 \%$ soy flour protein isolate was used.

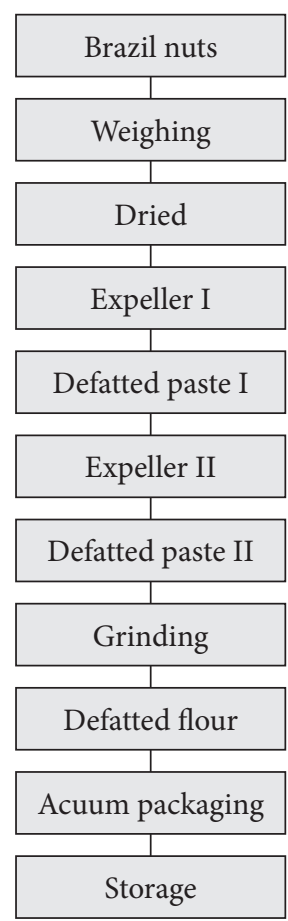

Figure 1. Flowchart for obtaining the defatted Brazil-nut flour.

The analyses were carried out using a Thermal sciences PL-STA piece of equipment, installed at the Geochemistry Laboratory of UFPA.

The samples were previously dried in an oven at $105^{\circ} \mathrm{C}$ and the following analyses were performed:

- Differential thermal analyses (DTA); and

- Thermogravimetric analysis (GTA).

\section{Morphological analysis of the defatted Brazil-nut flour}

For Scanning Electron Microscopy (SEM) analysis of the flour, the samples were previously defatted and dried in an oven at $105{ }^{\circ} \mathrm{C}$ for 48 hours, mounted on metal supports and metalized with gold, with a dimension close to $20 \mathrm{~nm}$ thick for 150 seconds in a 25 Ma current (SILVEIRA, 1989).

Electron micrographs were obtained from a LEO model 1450 VP scanning electron microscope belonging to the Laboratory of Scanning Electron Microscopy of the Coordination of Research and Post Graduation (CPPG) of Museu Paraense Emílio Goeldi (MPEG). The micrometric scale was projected under the same optical conditions.

\section{Results and discussion}

\subsection{Processing, obtaining and characterization of the flour}

The processes of elaboration and obtaining of the defatted flour were shown in the flowchart in Figure 1. The results of physico-chemical characterization are shown in Table 1.

The total energy value (TEV) found was an average $431.48 \mathrm{kcal} 100 \mathrm{~g}^{-1}$, which means a flour with high energetic 
value when compared to other types of flour such as cassava flour (energy value of $324.56 \mathrm{kcal}_{1} 100 \mathrm{~g}^{-1}$ ), tapioca flour (energy value of $360.93 \mathrm{kcal} .100 \mathrm{~g}^{-1}$ ) and soy flour (energy value of

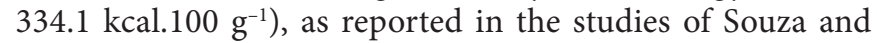
Menezes (2004), Dias and Leonel (2006) and Silva et al. (2006), respectively.

The water activity determined resulted in $0.24 \pm 0.03$, thus reflecting values expected due to loss of hydrophobic components in the lipid extraction stages and consequently a greater exposure of hydrophilic components, which resulted in a product regarded stable with a lower water activity.

The result found after moisture analyses of the defatted flour was $4.31 \pm 0.31$. This value represents, when analyzed in comparison to other studies, the lowest percentage of moisture in comparison to other types of flour, such as cassava flour $(12.78 \%)$ soy flour $(8.40 \%)$, respectively reported by Souza and Menezes (2004) and Silva et al. (2006).

The protein content is one of the main factors for a better food functionality of this flour. Quantitatively, it is the highest value, around $45.92 \pm 0.02\left(\mathrm{~g} .100 \mathrm{~g}^{-1}\right)$. Similar values were observed by Glória and Regitano-d Arce (2000), with a mean value of $47.6 \mathrm{~g} .100 \mathrm{~g}^{-1}$. In the studies by Souza and Menezes (2004), values around $40.23 \mathrm{~g} .100 \mathrm{~g}^{-1}$ were found. These values are far beyond the ones obtained by Ferreira et al. (2006) (a mean value of $28.34 \pm 0.18$ ).

This nutritional value presented by the defatted flour shows its potential in proteins, especially if compared to the values found for cassava and tapioca flours, respectively $1.21 \mathrm{~g} .100 \mathrm{~g}^{-1}$ and $0.02 \mathrm{~g} .100 \mathrm{~g}^{-1}$, very close to the protein content of soy flour ( 46.7 g. $100 \mathrm{~g}^{-1}$ ) (FERREIRA NETO; FIGUEIRÊDO; QUEIROZ, 2003; DIAS; LEONEL, 2006; SILVA et al., 2006).

A mean value of $26.09 \pm 0.79 \mathrm{~g} .100 \mathrm{~g}^{-1}$ was found for lipid content after extraction, which is considered an elevated value when compared to the one found in cassava flours (0.26 g.100 g ${ }^{-1}$ ) by Souza and Menezes (2004), or the one found in "tapioca" flour (around $0.13 \mathrm{~g} .100 \mathrm{~g}^{-1}$ ) by Dias and Leonel (2006), or even the one found in soybean (mean value of $1.67 \mathrm{~g} .100 \mathrm{~g}^{-1}$ ) by Silva et al. (2006).

The total dietary fiber content found $(17.14 \pm 0.32)$ indicates a product with a high content of this component, close to the values observed in the studies by Souza and Menezes

Table 1. Physical composition and physico-chemical of the defatted flour of Brazil nut.

\begin{tabular}{lc}
\hline \multicolumn{2}{c}{ Composition $\left(\mathrm{g} .100 \mathrm{~g}^{-1}\right)$} \\
\hline Energy $\left(\mathrm{kcal} .100 \mathrm{~g}^{-1}\right)$ & 431.48 \\
Aw & $0.24 \pm 0.03$ \\
Carbohydrate $^{*}$ & $3.25 \pm 0.04$ \\
Protein & $45.92 \pm 0.03$ \\
Lipid & $26.09 \pm 0.79$ \\
Dietary fiber & $17.14 \pm 0.32$ \\
Humidity (\%) & $4.31 \pm 0.33$ \\
Ashes & $3.29 \pm 0.02$ \\
\hline
\end{tabular}

Data represent the mean of three samples and the results are expressed as $\mathrm{g} .100 \mathrm{~g}^{-1}$ (b.u) Wet Weight. Mean \pm standard deviation. ${ }^{\star}$ Determined by difference.
(2004), (mean value of 15.72\%) and by Ferreira et al. (2006) $(18.32 \pm 0.19)$. In all these studies, higher values than the ones observed by Glória and Regitano-d Arce (2000) (mean value of $5.5 \%$ ) were found.

The content of carbohydrates calculated by difference was $3.25 \mathrm{~g} .100 \mathrm{~g}^{-1}$. This value was considered very low when compared to the result found by Souza and Menezes (2004) in cassava flour (79.33 g.100 g $\left.\mathrm{g}^{-1}\right)$; the content in "tapioca" flour (89.92 g.100 g ${ }^{-1}$ ) studied by Dias and Leonel (2006); and the content determined by Silva et al. (2006) in soy flour $\left(33.10 \mathrm{~g} .100 \mathrm{~g}^{-1}\right)$. The low carbohydrate content in Brazil-nut flour, when compared to other flours, is a good indication, since this value is directly related to plenty of protein, lipids and fibers in this raw material.

\subsection{Thermal analysis of the of the defatted Brazil-nut flour}

The differential thermal analysis (DTA) and gravimetric thermal analysis (GTA) of the flour are shown in Figure 2. GTA represents the loss of mass and DTA represents the energy involved when the samples are subjected to increasing temperatures.

Analyzing the graph in Figure 2a, b and c, it is possible to verify that the differential thermal analysis (DTA) curves present a single endothermal peak near the temperature of $100^{\circ} \mathrm{C}$. In this range, it is possible that the losses shown represent only water, given that they are always near the water boiling temperature.

In their studies on mass variations as a function of temperature ranges, Monthé and Azevedo (2002) state that such variations depend on characteristics of both the sample and the equipment used. The working temperature range chosen for this study aims to confirm possible moisture losses by the material, without employing any temperature elevation which could alter other nutritional components, lipids, proteins, fibers and others. Considering these possible alterations in the product when subjected to temperature variations, a working temperature range of $20^{\circ} \mathrm{C} /$ minute up to $300^{\circ} \mathrm{C}$ was determined.

Several studies on thermal stability have been carried out. However, few of them have approached food components. Analyses of cashew-nut oil can be found in the studies by Monthé and Azevedo (2002). These analyses indicate large variations in the degradation of compounds between 230 to $520{ }^{\circ} \mathrm{C}$. Another piece of research carried out by the authors refers to the characterization of milk powder with GTA. The techniques were used in studies on thermal degradation, determination of moisture, ash and purity. One of the analyses can be highlighted and serves as a parameter for the present work: the first degradation, that is the loss of moisture from milk in similar amounts to the ones observed in nut flour (nearly $4 \%$ when analyzed both in air and in nitrogen atmospheres).

ATG graph shows values of loss around 4\%, which confirms the moisture content of the material, determined in the physicochemical composition. Therefore, it is possible that such a mass loss, numerically determined and graphically shown by the endothermic peak, is the only structural modification in 
the flours. As the temperature approached $100{ }^{\circ} \mathrm{C}$, the water boiling point, the material did not present large interferences when soy protein isolate was added, rather showing the same behavior (Figure 2c).

This transformation may be a relevant factor for food processing, since it becomes a determining factor for a higher concentration of the other components, and also does not
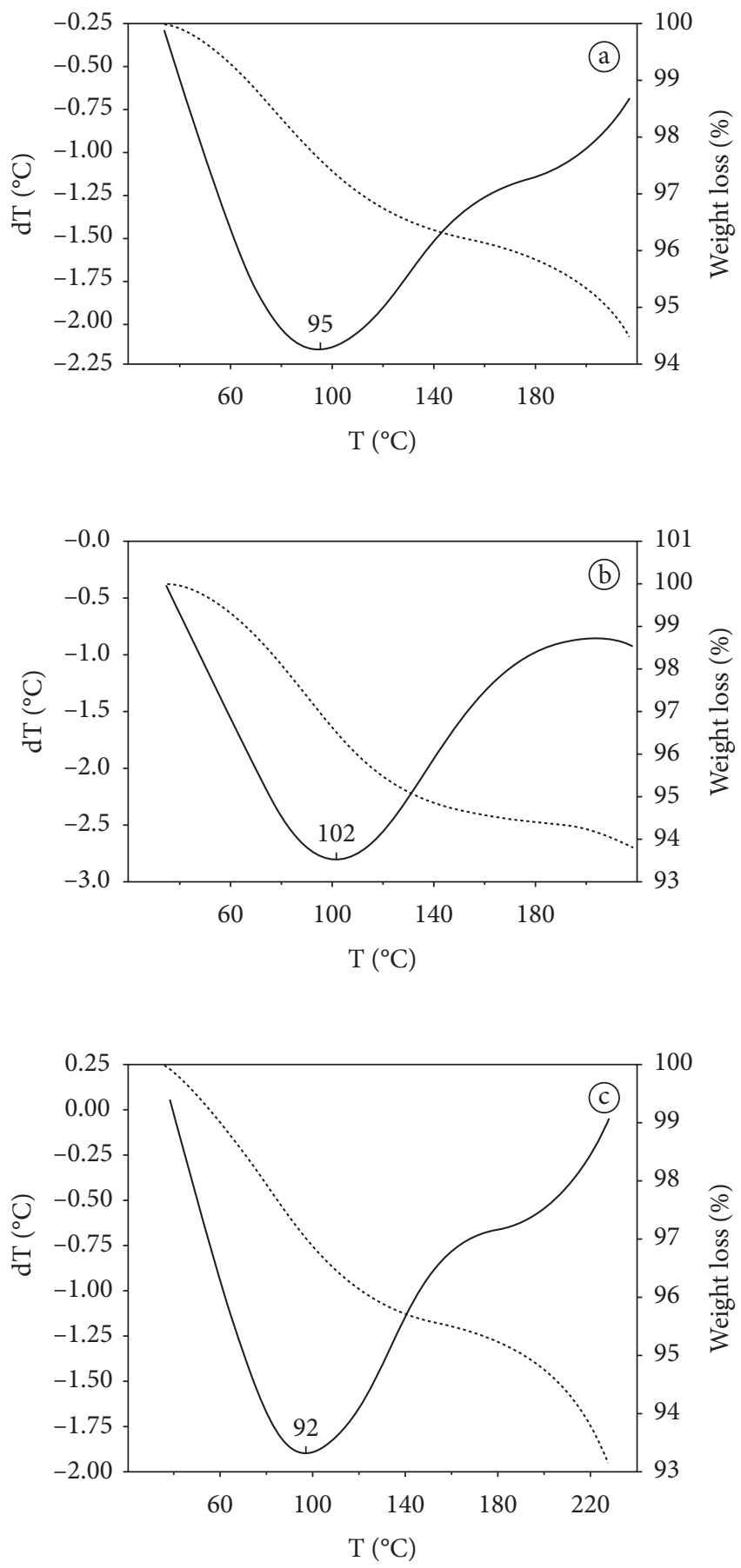

Figure 2. Gravimetric Thermal Analysis (GTA) and Differential Thermal Analysis (DTA) (-) of flours used: (a) defatted Brazil-nut flour, (b) isolated Soy protein, (c) mixed flour. interfere by diluting the fluid components of the formulations of these food products.

These data confirm the great diversity of uses of these flours for the food industry, without great losses and with a good stability at high temperatures as required in the elaboration and/ or enrichment of several products such as the ones produced by the pasta, bakery and confectionery industries, among other applications.

\subsection{Morphological analysis of the flour}

The micrographs show the major components found in the samples and their difference in the respective structures.

A heterogeneous composition in Brazil-nut flour can be observed in the micrographs (Figures 3 and 4), featuring irregular structures with indefinite shapes, rich in spongy-aspect material, with cavities and structural gaps of varied sizes.

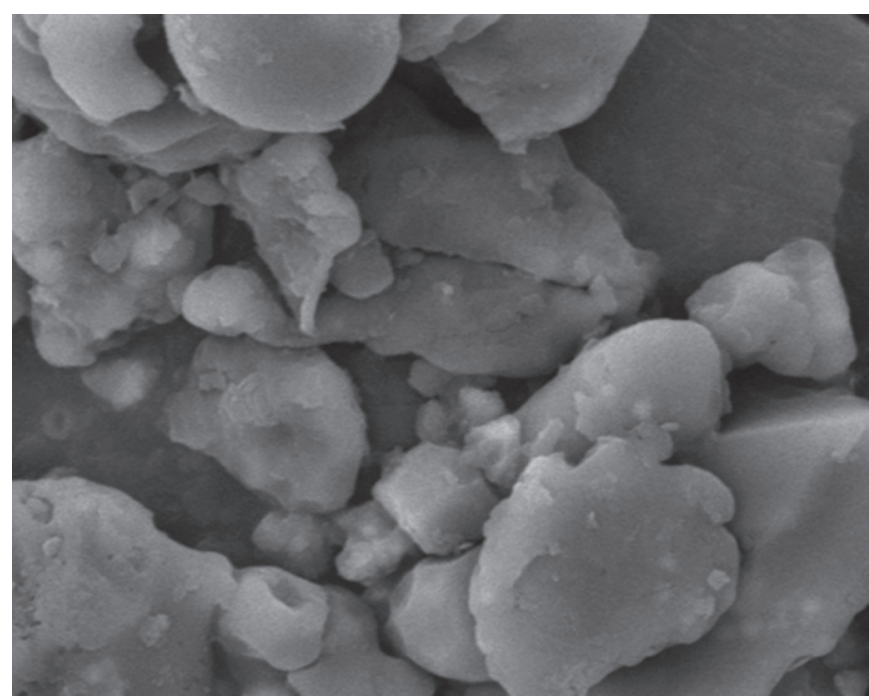

Figure 3. Defatted Brazil-nut granules.

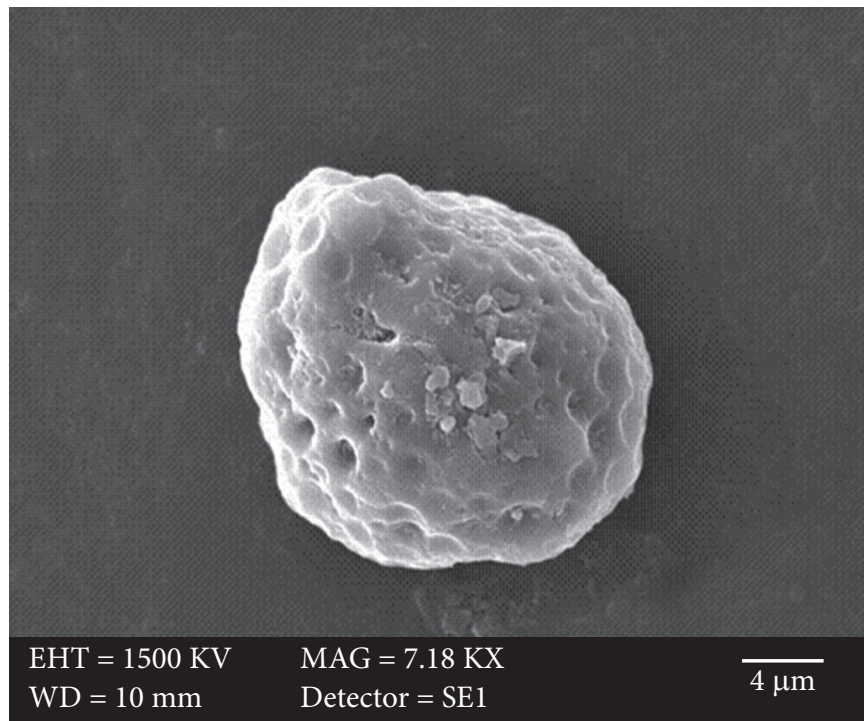

Figure 4. Defatted Brazil-nut flour granules. 


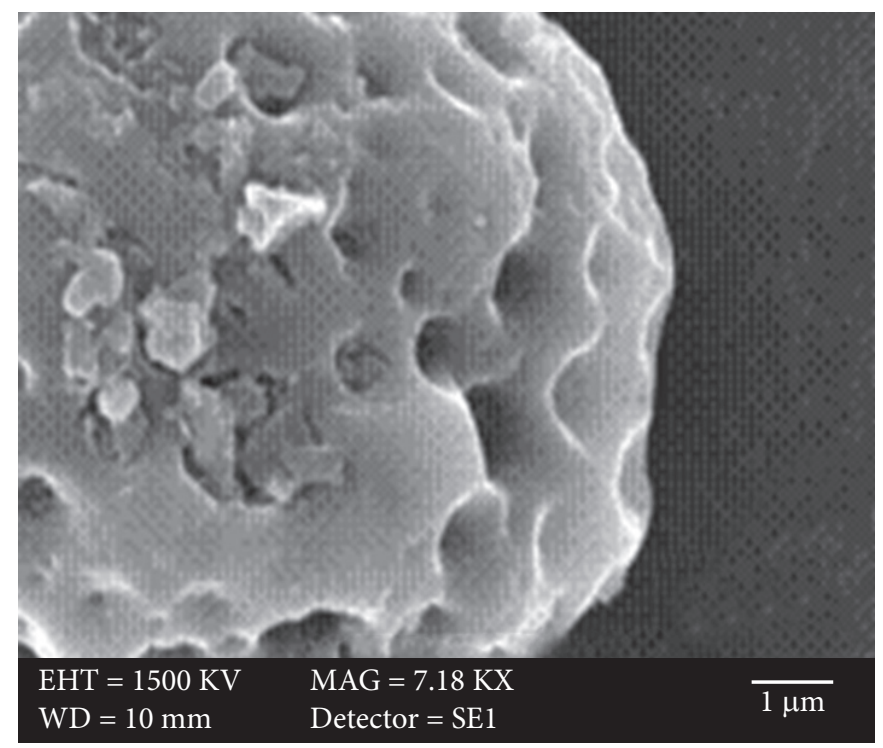

Figure 5. Detailed surface of the defatted Brazil-nut flour granule.

Figure 5 shows a detailed surface of a structure similar to the ones observed in the studies on proteins in oleaginous seeds of crucifers by Kirk and Pyliotis (1976). In this structure, a spongy aspect of the spherical or oval surface can be observed. This aspect is similar to the ones reported by Llluch, Pérez-Munuera e Hernando (2001). In the micrographs shown in their studies with oleaginous seeds, the authors stated that the shapes of the surfaces had been sculpted by lipid extraction, since lipids are closely related to the protein matrix and change its association with hydrophobic and hydrophilic structures after extraction.

In their studies, Shera and Sun (2009) analyzed the variations of peptide groups on surfaces with the same amino acid composition, although presenting different sequences, similar to soy protein, in different $\mathrm{pH}$ values. In this study, the formation of globular structures and cavities as a result of a probable release of matter and water expulsion from the matrix can be observed.

In the research by Bonelli et al. (2001), which evaluated the effects of thermal degradation rate on Brazil-nut shells in the temperature range of 25 to $900^{\circ} \mathrm{C}$, the authors concluded that pyrolysis of the nut shell led to significant changes in the chemical, textural and morphological characteristics, in addition to the formation of micropores on the surface.

Although each protein features a unique pattern, similarities can be verified, such as structural models which appear on different proteins, models which may lead to the development of databases which allow comparisons from information concerning protein structures (NELSON; COX, 2002; LLUCH; PÉREZ-MUNUERA; HERNANDO, 2001).

\section{Conclusions}

- Brazil-nut flour processing proved nutritionally viable, keeping high levels of energy and protein and elevated total dietary fiber content;
- Thermal analyses showed that the introduction of another protein component, such as soy protein isolate, does not alter the reactions or thermal behavior;

- The results of ATD and ATG curves in the proposed temperature range only showed an exothermic variation in all samples;

- Morphological analyses show, in the granule structure, forms of similar pattern to the structure of globular protein matrices;

- After processing, the product maintained its high energyprotein content and preserved its characteristics when subjected to high temperatures; and

- These parameters raise the possibility of implementing the use of this product in the food industry, either as a basic raw material or as an enriching component for other blends, with wide possibilities of application in the bakery, confectionery, pastry, general pasta, and the meat product industries, in addition to the possibility of both qualitative and quantitative enhancement in several industry segments.

\section{References}

ASSOCIATION OF OFFICIAL ANALYTICAL CHEMISTS - AOAC. Official methods of analysis. $16 \mathrm{ed}$. Virginia, 1997.

BONELLI, P. R. et al. Effect of pyrolysis temperature on composition, surface properties and thermal degradation rates of Brazil nuts shells. Bioresource Technology, v. 76, n. 1, p. 15-22, 2001.

BOWLES, S.; DEMIATE, I. M. Caracterização físico-química de Okara e aplicação em pães do tipo francês. Ciência e Tecnologia de Alimentos, v. 26, n. 3, p. 652-659, 2006.

CAMARGO, I. P.; CASTRO, E. M.; GAVILANES, M. L. Aspectos da anatomia e morfologia de amêndoas e plântulas de castanheira-doBrasil. Revista CERNE, v. 6, n. 2, p. 11-18, 2000.

CARDARELLI, H. R.; OLIVEIRA, A. J. Conservação do leite de castanha-do-Pará. Scientia Agrícola, v. 57, n. 4, p. 617-622, 2000.

COUTINHO, V. F.; COZZOLINO, S. M. F. Análise da concentração de selênio em castanhas do Pará (Bertholletia excelsa, H. B. R.) In: CONGRESSO BRASILEIRO DE NUTRIÇÃO SEGURANÇA ALIMENTAR E NUTRICIONAL NO BRASIL, 1998, Brasília. Anais...

DIAS, L. T.; LEONEL, M. Caracterização físico-química de farinhas de mandioca de diferentes localidades do Brasil. Ciência Agrotécnica, v. 30, n. 4, p. 692-700, 2006

FERBERG, I. et al. Efeito das condições de extração no rendimento e qualidade do leite de castanha-do-brasil despeliculada. Boletim do Centro de Pesquisa e Processamento de Alimentos, v. 20, n. 1, p. 75-78, 2002.

FERREIRA NETO, C. J.; FIGUEIRÊDO, R. M. F.; QUEIROZ, A. J. M. Avaliação físico-química de farinhas de mandioca durante o armazenamento. Revista Brasileira de Produtos Agroindustriais, v. 5, n. 1, p. 25-31, 2003.

FERREIRA, E. S. et al. Caracterização físico-química da amêndoa, torta e composição dos ácidos graxos majoritários do óleo bruto da Castanha-do-brasil (Bertholletia excelsa H. B. K). Alimentos e Nutrição, v. 17, n. 2, p. 203-208, 2006.

GLÓRIA, M. M.; REGITANO-D’ARCE, M. A. B. Concentrado e isolado protéico de torta de castanha-do-Pará: obtenção e caracterização 
química e funcional. Ciência e Tecnologia dos Alimentos, v. 20, n. 2, p. 240-245, 2000.

GONZAGA, I. B. Avaliação nutricional relativa ao selênio, em crianças com dieta enriquecida de castanha-do-brasil (Bertholletia excelsa). São Paulo, 2002. 161 p. Tese (Doutorado em Ciências dos Alimentos) - Universidade de São Paulo - UNESP.

IÑARRITU, M. C.; FRANCO, L. V. Las barras de cereales como alimento funcional en los niños. Revista Mexicana de Pediatria, v. 68 , n. 1, p. $8-12,2001$.

KIRK, J. T. O.; PYLIOTIS, N. A. Cruciferous oilseed proteins: the protein bodies of sinapis alba seed . Australian Journal of Plant Physiology, n. 3, p. 731-746, 1976.

LLUCH, M. A.; PÉREZ-MUNUERA, I.; HERNANDO, I. Proteins in food structures. In: SIKORSKI, Z. E. (Ed.). The chemical and functional properties of food proteins. Pennsylvania: Technomic Publishing Company, 2001. p. 13-33.

MONTHÉ, C. G.; AZEVEDO, A. D. Análise térmica de materiais. São Paulo: iEditora, 2002. 300 p.

NELSON, D. L.; COX, M. M. Lehninger princípios de bioquímica. 3 ed. São Paulo: Sarvier, 2002. 975 p.

SGARBIERI, V. C. Proteínas em alimentos protéicos: propriedades, degradações, modificações. São Paulo: Varela, 1996. 517 p.
SILVEIRA, M. O. O preparo de amostras biológicas para microscopia de varredura eletrônica. In: SOUZA, W. (Ed.). Manual sobre técnicas básicas em microscopia eletrônica de varredura: técnicas básicas. Rio de Janeiro: Sociedade Brasileira de Microscopia Eletrônica, 1989. p. 172-82. (v. 1)

SOUZA, E. B. Análise do processamento de secagem de castanha-dobrasil (Bertholletia excelsea) em secador de bandejas utilizando planejamento estatístico de experimentos. Belém, 1999. 188 p. Dissertação (Mestrado em Engenharia Química) - Universidade Federal do Pará - UFPA.

SOUZA, M. L.; MENEZES, H. C. Processamento de amêndoa e torta de castanha-do-brasil e farinha de mandioca: parâmetros de qualidade. Ciência e Tecnologia de Alimentos, v. 24, n. 1, p. 120-128, 2004.

SILVA, M. S. et al. Composição química e valor protéico do resíduo de soja em relação ao grão de soja. Ciência e Tecnologia de Alimentos, v. 26, n. 3, p. 571-576, 2006.

SHERA, J. N.; SUN, X. S. Effect of Peptide Sequence on Surface Properties and Self-Assembly of an Amphiphilic pH-Responsive Peptide. Biomacromolecules, v. 10, n. 9, p. 2446-2450, 2009.

VILHENA, M. R. Ciência, tecnologia e desenvolvimento na economia da castanha-do-brasil. Campinas, 2004. 120 p. Dissertação (Mestrado em Política Científica e Tecnológica) - Universidade Estadual de Campinas - UNICAMP. 